\title{
Optimisation of hot-water application technology for the control of broad-leaved dock (Rumex obtusifolius)
}

\author{
Roy Latsch, Joachim Sauter \\ Agroscope, Institute for Sustainability Sciences ISS, Ettenhausen, Switzerland
}

\begin{abstract}
In organic farming, the control of broad-leaved dock (Rumex obtusifolius) via hot-water treatment of the upper root region (hypocotyl) is a new alternative to the current standard control method involving manual digging-out of the roots. This comparative study looks at five different hot-water application techniques. The aim is to optimise the control method in terms of water and energy requirement to obtain a mortality rate of the treated plants of at least $80 \%$. The studied parameters were the application, the amount of water, the water temperature, the soil moisture content and the soil type. In total, 813 plants of varying size were treated (120-225 plants per treatment). The success of each treatment was rated 12 weeks after it was applied. Based on the results, the preferred treatment in terms of water and energy requirement was a commercially available rotary nozzle. With this nozzle, for example, at 40 vol.-\% soil moisture, $1.6 \mathrm{~L}$ of water at a temper-
\end{abstract}

Correspondence: Roy Latsch, Agroscope, Tänikon 1, CH-8356 Ettenhausen, Switzerland.

Tel.: +41.58.480.33.63 - Fax: +41.52.365.11.90.

E-mail: roy.latsch@agroscope.admin.ch

Key words: Rumex obtusifolius, broad-leaved dock, weed control, thermal treatment, organic farming.

Acknowledgements: we would like to thank the Dällikon, Switzerland, subsidiary of Kärcher AG for providing us with the hot-water high-pressure cleaner for the field trials.

Contributions: RL, data collecting and analysing, manuscript writing; JS, data collecting and manuscript reviewing.

Conflict of interests: the authors declare no potential conflict of interests.

Conference presentation: Part of this paper was presented at the 12 . Wissenschaftstagung Ökologischer Landbau: Ideal und Wirklichkeit Perspektiven ökologischer Landbewirtschaftung, 05.-08.03.2013, Bonn, Germany.

Received for publication: 16 June 2014.

Accepted for publication: 26 September 2014.

(C) Copyright R. Latsch and J. Sauter, 2014

Licensee PAGEPress, Italy

Journal of Agricultural Engineering 2014; XLV:239

doi:10.4081/jae.2014.239

This article is distributed under the terms of the Creative Commons Attribution Noncommercial License (by-nc 3.0) which permits any noncommercial use, distribution, and reproduction in any medium, provided the original author(s) and source are credited. ature of $90^{\circ} \mathrm{C}$ was necessary for successful Rumex control. The rotary nozzle could be used as a non-contact system, and was therefore the most user-friendly of the application techniques examined.

\section{Introduction}

Throughout Europe, grassland areas managed according to organic-farming principles are increasing. The percentage of organically managed areas in the whole of the $\mathrm{EU}$, for example, rose from 5,913,359 hectare (ha) in 2004 to 7,542,604 ha in 2008 (Köpke et al., 2011). In Switzerland, the percentage of these areas has remained practically constant over the last nine years and, at 116,188 ha in 2011 , accounted for $11 \%$ of the total agricultural area (Bundesamt für Statistik BfS, 2012).

One of the greatest problems in organically managed grassland is posed by broad-leaved dock, Rumex obtusifolius (Zaller, 2004). Broadleaved docks contain high levels of oxalic acid and oxalates, which can cause health problems in large doses (Brune, 1955; Roth et al., 2012). Avoided by grazing animals on account of the substances it contains, the plant causes reduction in livestock performance when present in conserved feed. Oswald and Haggar (1983) reckoned that a ground cover of 20-30\% broad-leaved dock would reduce the vegetation volume of valuable fodder plants up to $20 \%$. To avoid these negative effects, the dock stocking on grassland should be minimal.

Differing from other weeds, the physical control of broad-leaved dock is difficult because of the growth and the regenerative power of its taproots. The primary taproot of the dock develops in the first year after germination (Bond and Turner, 2003). In the second year, the plant produces secondary taproots (Pino et al., 1995). Thereafter, the taproot system increases and divides. The clonal growth of one plant can affect large weed-covered areas (Bond and Turner, 2003). The regenerative power of $R$. obtusifolius lies in the hypocotyl. It is about $0.1 \mathrm{~m}$ long and located in the first section of the partially very complex underground organs (Roberts and Hughes, 1939). Stored reserve materials enable the plant to resprout quickly after mowing. The hypocotyl part needs to be totally removed or killed to get rid of established plants.

Another unfavourable capacity or $R$. obtusifolius is its enormous production of seeds. One single plant can produce up to 60,000 seeds per year (Cavers and Harper, 1964; Foster, 1989; Sobotik, 2001), which can remain germinable up to $83 \%$ after 21 years (Toole and Brown, 1946). Hunt and Harkess (1968) found 5,000,000 seeds per acre (equals 1236 seeds per square metre) in the upper $15 \mathrm{~cm}$ of a pasture. The seeds need light to germinate. So wherever there is sparse plant cover, R. obtusifolius can move in (Bond and Turner, 2003). Moreover, if hay or grass silage is contaminated with dock seeds, these can be spread over all plots of the farm via the slurry cycle (Zaller, 2007).

To date, the standard method for controlling dock in organic farming is to dig up the roots by hand at a depth of about $0.1-0.15 \mathrm{~m}$, and to remove the hypocotyl part from the grassland site. Although very effective, this method is time consuming and physically strenuous. 
Moreover, the damage to the sward gives seeds a chance to germinate.

In the literature, five different approaches to control dock plants can be distinguished: i) adapted grassland management procedures like nontillage, grazing regimes, frequency of grassland use and fertilisation strategies (Niggli et al., 1993; Hopkins and Johnson, 2002; Briemle and Rück, 2006; Zaller, 2006; Starz et al., 2010); ii) bio herbicides like acetic acid, saline solution, citronella oil or pelargonic acid (Boller, 2006; Massucati et al., 2009); iii) natural enemies of dock plants like pathogens and insects (Grossrieder and Keary, 2004); iv) mechanical treatment with different tools like mechanical grabbers or rotary tillers (Böhm and Finze, 2004; Pötsch and Griesebner, 2007; Sauter et al., 2012); v) and thermal treatments, which are relevant for this investigation. Therefore, only thermal treatments, such as laser application, microwave, flame treatment or steam/hot-water treatment, will be discussed.

As already specified, the key to controlling broad-leaved dock lies in the elimination of the hypocotyl tissue. Therefore, above-ground control techniques like laser application (Mathiassen et al., 2006), flame treatment (Bertram, 1996; Böhm and Verschwele, 2004) or steam/hotwater treatment of the sprout (Hansson and Mattsson, 2002; Sirvydas et al., 2002; Kerpauskas et al., 2006; Merfield et al., 2009), which do not affect the plant's ability to resprout from its taproots, can be discarded beforehand. Thermal treatments that are able to reach the hypocotyl zone are microwave, infrared technology and soil disinfection through direct steam or hot-water application.

Microwave treatment was positively tested to control weed seeds and pathogens in soils (Gracia-López and Velázquez-Martí, 2002; Velázquez-Martí and Gracia-López, 2004; Velázquez-Martí et al., 2008). Although microwaves could be used to control broad-leaved dock, they are unsuitable because of the very high energy consumption (Dürr et al., 2005; Latsch et al., 2009; Latsch and Sauter, 2010).

With infrared gas technology, a metal spike heated to $600^{\circ} \mathrm{C}$ is driven into the dock root (Pötsch, 2001). This technology could not be established in practice. In our own investigations, we tested metal spikes of $25 \mathrm{~mm}$ diameter and $120 \mathrm{~mm}$ length. These spikes were heated in a muffle furnace to $600^{\circ} \mathrm{C}$ in one test series with 70 plants and to $800^{\circ} \mathrm{C}$ in a second test series with 100 plants. The mortality rate was less than $75 \%$ in every trial and therefore insufficient. In addition, the handling of the extremely hot spikes was unacceptable for practical use. Infrared technology was therefore rejected as a possible solution for dock control. Steam application is an appropriate procedure to disinfect soil. Mostly, this method is used for extensive areas. For better results, chemical additives with exothermic reactions like potassium hydroxide $(\mathrm{KOH})$ or calcium oxide $(\mathrm{CaO})$ are sometimes used (Barberi et al.,
2002; Barberi et al., 2009). For example, the patented bioflash system uses a self-propelled machine to disinfect soil in greenhouses by incorporating steam and additives with a rotary hoe into tilled soil (Peruzzi et al., 2002; Peruzzi et al., 2011; Peruzzi et al., 2012). Neither in Swiss nor in European organic farming is the outdoor-use of such additives allowed. The prevailing lists of additives in organic farming only allow these additives as disinfectants in buildings for livestock (European Commission, 2008; Forschungsinstitut für biologischen Landbau FiBL, 2014). Hence, other ways to produce an adequate temperature are necessary. Until today, steam application was not used for the single plant control of root spreading weeds.

In an own laboratory pretest conducted in 2009 , dock roots were plunged into water at an average temperature of $88^{\circ} \mathrm{C}$. The aim was to heat the dock roots initially to $80^{\circ} \mathrm{C}$ (the melting point of nucleic acids) to irreversibly damage the DNA of the roots, thereby killing them. This test resulted in $100 \%$ mortality of the plants after just 10 seconds. The shortness of the necessary exposure time suggests that heating the outer root-cell layer capable of producing shoots is sufficient to control dock. The subsequent field trials in 2010 produced good results with a hot-water/steam mixture with temperatures up to $145^{\circ} \mathrm{C}$ (Latsch $e t$ al., 2011). To achieve the targeted mortality rate of at least $80 \%$, an average of $2.4 \mathrm{dm}^{3}$ heated water was required at a soil moisture of up to $30 \mathrm{vol.}-\%$ (Latsch et al., 2011).

A major advantage of this method is that the treated roots do not need to be extracted and disposed but can remain in the soil. In the 2010 field trials, however, the energy input for generating steam did not meet the demands of a method ready for practical application. The aim of this study was therefore to optimise the application technology in terms of its water and energy requirement.

\section{Materials and methods}

\section{Site}

The treatments were conducted in 2011 in plots on an experimental farm in Tänikon, Ettenhausen, Switzerland. Tänikon is located $540 \mathrm{~m}$ above sea level and has an average annual precipitation of $1200 \mathrm{~mm}$. Five grassland sites served as experimental plots (Table 1).

\section{Experimental vehicle}

A commercially available high-pressure cleaner with a steam stage

Table 1. Brief description of the experimental plots at the time of the trial.

\begin{tabular}{|c|c|c|c|c|}
\hline $\begin{array}{l}\text { Experimental plot } \\
\text { (No.) }\end{array}$ & Soil type & Date & $\begin{array}{l}\text { Soil moisture } \\
\text { (vol.-\%) }\end{array}$ & No. of plants \\
\hline 1 & Clay loam & $24 / 06 / 2011$ & 31.6 & 77 \\
\hline 2 & & $26 / 07 / 2011$ & 38.6 & 165 \\
\hline 2 & & 02/08/2011 & 32.5 & 75 \\
\hline 2 & & 23/08/2011 & 36.1 & 120 \\
\hline 2 & & 24/08/2011 & 32.5 & 60 \\
\hline 2 & & $25 / 08 / 2011$ & 32.9 & 60 \\
\hline 3 & Medium sandy loam & 05/07/2011 & 36.8 & 45 \\
\hline 3 & & 06/07/2011 & 31.9 & 15 \\
\hline 3 & & 06/07/2011 & 36.8 & 46 \\
\hline 4 & & 11/08/2011 & 39.1 & 90 \\
\hline 5 & Weakly silty clay & 18/07/2011 & 45.0 & 60 \\
\hline
\end{tabular}


(type: HDS 9/18-4 M, Alfred Kärcher GmbH \& Co. KG, Winnenden, Germany) was used to generate hot water. A trailer transported the high-pressure cleaner, the water tank, and an additional tank for recording the amount of fuel-oil (Figure 1). A mobile $380 \mathrm{~V}$ (15 kVA) generator supplied the unit with electricity (Latsch et al., 2011).

\section{Application heads and procedure}

Four different application heads (A-D) were designed to treat the plants with the hot-water/ steam mixture. In addition, a rotation nozzle (E) (Kärcher 'Dirt blaster' type, Alfred Kärcher GmbH \& Co. KG) was used (Figure 2). The hose was $10 \mathrm{~m}$ long. When we designed the appli-

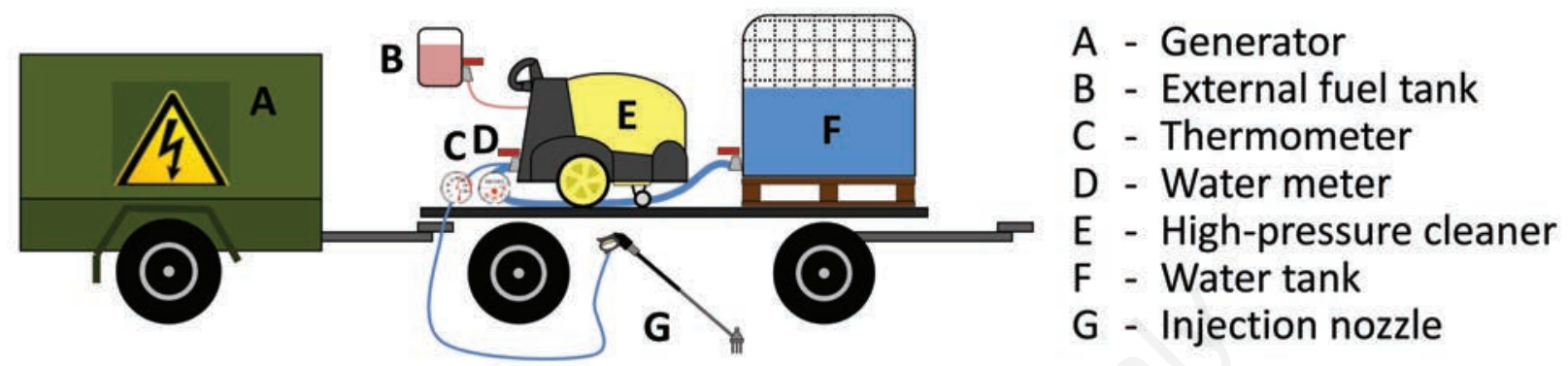

Figure 1. Scheme of the experimental vehicle.

A

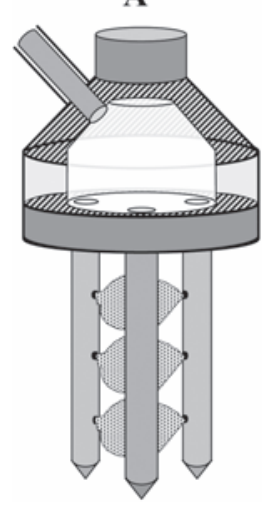

B

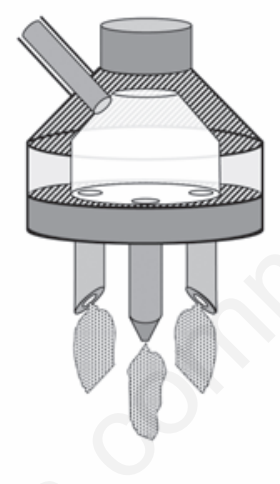

C

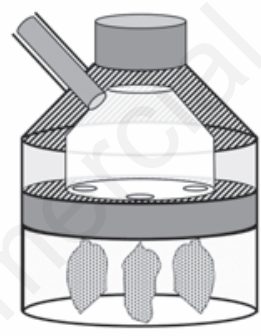

D

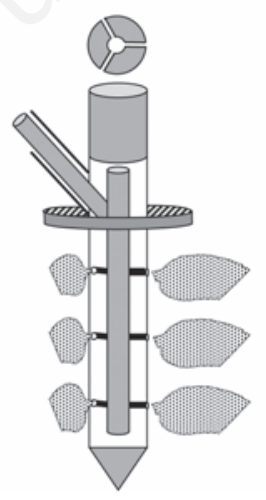

$\mathbf{E}$

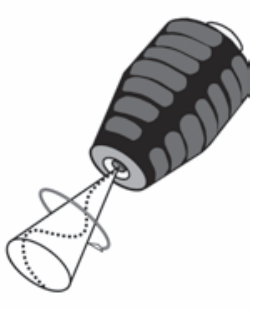

Figure 2. Sketches of the used application heads.

Table 2. Technical data of the used application heads.

\begin{tabular}{|c|c|c|c|c|c|c|}
\hline \multirow{2}{*}{ Technical data } & \multirow{2}{*}{ Unit } & \multicolumn{5}{|c|}{ Treatment } \\
\hline & & A & B & C & D & $\mathbf{E}$ \\
\hline Distance between spikes & $\mathrm{mm}$ & 43 & 43 & 43 & - & - \\
\hline Spike diameter & $\mathrm{mm}$ & 12 & 12 & - & 16 & - \\
\hline Nozzle bore & $\mathrm{mm}$ & $9 \times 1.0$ & $3 \times 1.2$ & $3 \times 1.4$ & $9 \times 1.0$ & $1 \times 1.8$ \\
\hline Nozzle area total & $\mathrm{mm}^{2}$ & 7.1 & 3.4 & 4.6 & 7.1 & 2.5 \\
\hline Nozzle distance & $\mathrm{mm}$ & 30 & - & - & 30 & - \\
\hline Flow rate mean \pm SD & $\mathrm{dm}^{3} / 60 \mathrm{~s}$ & $9.0 \pm 1.3$ & $8.9 \pm 0.2$ & $9.6 \pm 1.5$ & $8.8 \pm 0.4$ & $8.9 \pm 0.5$ \\
\hline Water injection to a depth of & $\mathrm{mm}$ & 90 & 30 & 0 & 90 & - \\
\hline \multicolumn{7}{|l|}{ Experimental settings } \\
\hline Duration of treatment & s & & 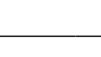 & $0,15,20$ & & \\
\hline Temperature pre-selection(s) & ${ }^{\circ} \mathrm{C}$ & $95 / 120$ & $95 / 120$ & $95 / 120$ & $95 / 120$ & 95 \\
\hline Water pressure & $\mathrm{kPa}$ & 3200 & 3200 & 3200 & 3200 & 7000 \\
\hline No. of plants treated & units & 153 & 225 & 120 & 180 & 135 \\
\hline
\end{tabular}


cation heads (A-D), the primary concern was to bring the water as close as possible to the top root section of the dock plants. Thereby the water flow rate per application head had ideally to be equal (Table 2). Another important aspect was the fault liability of the heads, which had to work in a muddy application field.

Treatment A was a refined version of the head used in 2010 (Latsch et al., 2011) with an optimised water flow rate. The idea was to encircle the taproot with three spikes that inject the hot water with nine spray holes into their centre to a depth of $90 \mathrm{~mm}$.

Treatment B had shorter spikes than Treatment A with three vertical spray holes. The shortened spikes should prevent breakage in stony soil. The bigger spray holes should guard against water flow blockage. With the spray holes directed downwards, the taproot should be totally enclosed with water.

With Treatment C, the construction of Treatment B was further reduced. The head had no spikes, but a ring that was pushed into the soil approximately $10 \mathrm{~mm}$ deep. It should keep the applied amount of water from escaping laterally and guide the water into the soil. The three vertical nozzles were placed above ground, so they had no contact with the soil.

Treatment D was driven directly into the middle of the dock shoot and conveyed the water through nine spray holes horizontally into the soil down to a depth of $90 \mathrm{~mm}$.

Whereas the heads of Treatments A-D had to be hammered into the ground, Treatment E's handling was different: the rotation nozzle was placed vertically on the ground and guided around and across the plant shoot. The rotating spot jet destroyed the soil structure, leaving behind an earth/water mixture that enveloped the root.

The hot water was applied in test series of 15 plants each. The treated plants were selected so that no other dock plants stood in striking distance and could potentially falsify the results. The planned duration of treatment was recorded by stopwatch, whilst the amount of water actually required was recorded with a water meter (Aquametro, type: Saphir, $\mathrm{d}=0.0001 \mathrm{~m}^{3}$, Basel, Switzerland) at the inlet of the device.

The adjusted pre-selection temperature of the high-pressure cleaner could not be measured. The water temperature at its outlet was recorded once with an accurateness of $5^{\circ} \mathrm{C}$ at the end of each treatment (thermistor type Kärcher). With Treatments A-D, the recorded temperature ranged from $70-150^{\circ} \mathrm{C}$. As per the manufacturer's instructions, Treatment $\mathrm{E}$ was not operated in hot-steam mode. Because the preselected temperature was $95^{\circ} \mathrm{C}$, the recorded temperature range was lower than that in the other treatments.

For each test series, the quantity of fuel-oil required to heat the water was determined gravimetrically (Scale Ohaus, type DS10, d=0.02 kg, Nänikon, Switzerland). Soil moisture was determined on a volume basis in undisturbed soil samples $\left(0.1 \mathrm{dm}^{3}\right)$ taken from a depth of $0-0.1 \mathrm{~m}$ (dried at $105^{\circ} \mathrm{C}$ ). The treated plants were mapped with an RTK GNSS (real-time kinematic Global Navigation Satellite System, Trimble R8, Sunnyvale, CA, USA) to aid in their relocation during the visual appraisal after 4, 8 and 12 weeks. This period should be long enough, according to Pino et al. (1995), who stated that the regeneration of subterranean plant parts takes 12 days.

The statistical analysis was conducted with Tibco Spotfire $S+{ }^{\circledR} 8.1$ for Windows (Somerville, MA, USA). A logistic regression was performed with a generalised linear mixed-effects model. The influence of the application heads, water amount, water temperature and soil moisture on the resprouting of the dock plants was investigated.

\section{Water distribution in the soil}

In a separate trial at a site with clay loam soil, water distribution in the soil was determined by tracing water that had been dyed blue. In this test, three plants were treated with each application head with $2 \mathrm{dm}^{3}$ of a $0.3 \%$ solution of the dye Vitasyn Blue (Clariant $\mathrm{GmbH}$, Frankfurt/Main, Germany) according to the procedures described above. After the application, five vertical soil profiles were dug per plant and photographed with a digital camera (Nikon D5100, Nikon Corp., Tokyo, Japan). The profiles were positioned in the plane of the taproot, as well as parallel to this plane 0.05 and $0.1 \mathrm{~m}$ from it in both directions (Figure 3). The photos were analysed with an in-house software program (BMP tool; Anken et al., 1999). Here, the number of blue-dyed image pixels per unit area were counted. Based on the idea that with an optimal treatment the water should be concentrated directly around the root, the area measuring $0.1 \times 0.1 \times 0.1 \mathrm{~m}$ around the plant was examined. To determine whether the methods differed in the water distribution, three image planes were added up to a total result (Figure 3), and a one-factorial analysis of variance was performed with the software Tibco Spotfire $\mathrm{S}_{+}{ }^{\circledR}$.

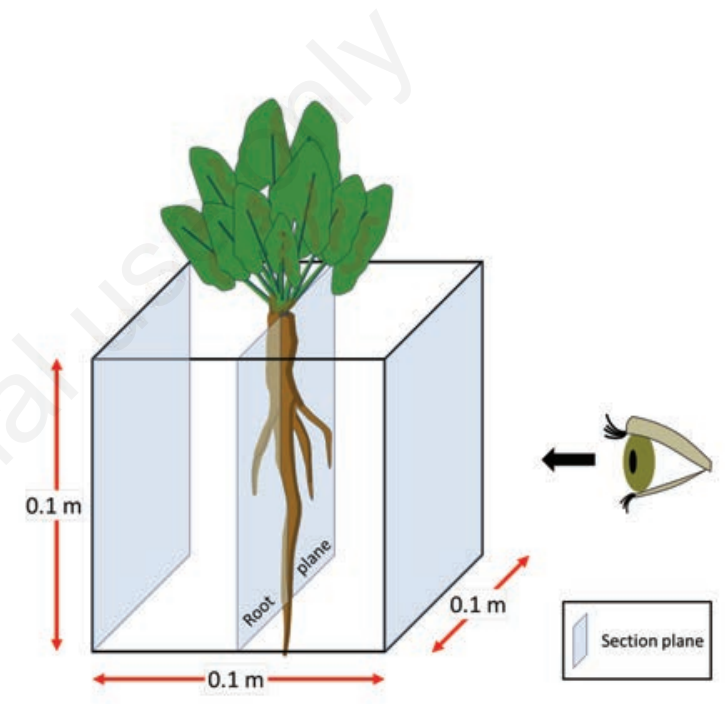

Figure 3. Sketch of the experimental design with three section planes where water distribution was examined.

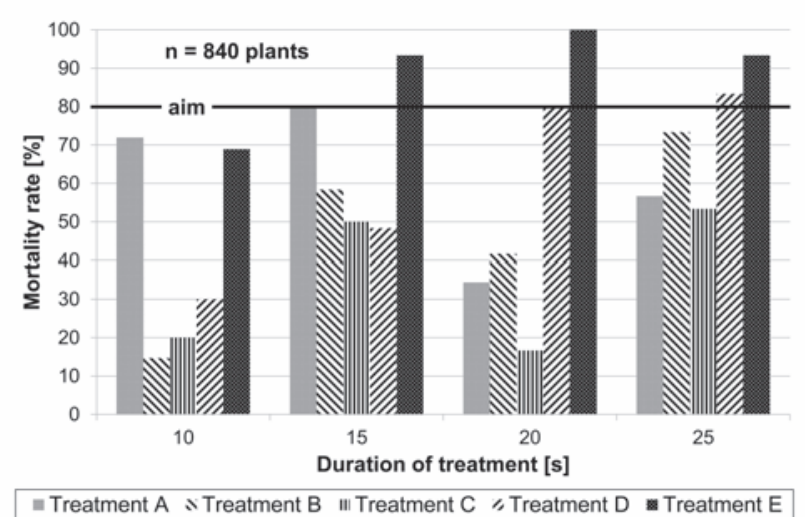

Figure 4. Mortality rate as a function of duration of treatment. 


\section{Results}

\section{Water and energy requirement}

A first overview (Figure 4) showed that the mortality rate did not increase with increasing duration of treatment in the same way for all treatment variants. Treatment A produced suitable and increasing mortality rates at 10 and $15 \mathrm{~s}$, but at a longer duration of the treatment, the intended mortality rate of $80 \%$ was not reached. Treatments B and C showed increasing mortality rates when the duration of treatment increased from 10-25 s, with the exception of $20 \mathrm{~s}$ where the mortality rate was much lower than at shorter durations of treatment. Both treatments did not reach the intended mortality rate of $80 \%$ in any case. Treatment D achieved the goal with exposure of $20 \mathrm{~s}$ or more. Only Treatment E exceeded the aimed mortality rate when the treatment lasted $15 \mathrm{~s}$ or longer. All treatments occurred under field conditions at different sites that varied in the root sizes and habits, the positioning and functioning of the application heads, the water temperature and the soil conditions. This variability could explain why the mortality did not increase linearly with increasing treatment time or temperature.

In the logistic regression of the linear mixed-effects model (Eq. 1), fixed effects were: the treatment, the water temperature and the water amount (Table 3). Soil moisture was a random effect. Soil type was not taken into account owing to the low quantity of data. As already written, the outcome variable mortality rate was defined as 0.8 .

$P[$ mortality $\quad$ rate $]=[0.8]=I n v \quad$ logit $\quad(8.913+\beta T r+0.071 * T-0.049 *$ $M_{H 2 O}-0.602 * \theta+1.578+\beta \operatorname{Tr} T^{*} T+\beta \operatorname{Tr} M^{*} M_{H 2 O}-0.038^{*} T^{*} M_{H 2 O}+0.180^{*}$ $M_{H 20} * \theta+\beta \operatorname{TrTM}^{*} T^{*} M_{H 2 O}$ )

where:

$\mathrm{M}_{\mathrm{H}_{2} \mathrm{O}}$ is the water-amount;

$T$ is the water temperature $\left({ }^{\circ} \mathrm{C}\right)$;

$\theta$ is the soil moisture $\left(\mathrm{m}^{3} \mathrm{~m}^{-3}\right)$;

$\beta T r$ is the coefficient of treatment;

$\beta \operatorname{Tr} T$ is the coefficient of treatment:temperature; $\beta T r M$ is the coefficient of treatment:water-amount;

$\beta T r T M$ is the coefficient of treatment:temperature:water-amount.

In the graphic representation of the statistical analysis (Figure 5), the different isolines correspond to a mortality rate of $80 \%$, with the different line thicknesses symbolising soil moistures of 40 and 45 vol.- $\%$. The ranges above the respective isolines represent the target range of the mortality rate $>80 \%$.

Soil moisture of the complete dataset ranged from 31.6-45.0 vol.-\%. The thermal energy required to heat the soil rises with increasing soil moisture because the additional soil water must be heated. Here, the achievable temperature increase differs according to soil type and soil moisture content. With the same thermal-energy content, the amount of water applied and the water temperature are reciprocally proportional (Eq. 2).

$$
\mathrm{E}_{\mathrm{th}}=\mathrm{c} \times \mathrm{m} \times \Delta \mathrm{T}
$$

where:

$\mathrm{E}_{\text {th }}$ is the thermal energy $(\mathrm{kJ})$;

$\mathrm{c}$ is the heat capacity $\left(\mathrm{kJ} \mathrm{kg}^{-1} \mathrm{~K}^{-1}\right)$;

$\mathrm{m}$ is the mass $(\mathrm{kg})$;

$\Delta \mathrm{T}$ is the temperature difference $(\mathrm{K})$.

With Treatments A and B, this dependency was clearly visible, and low water temperature could be substituted by an increased water amount, and vice versa. With the remaining treatments, this relationship was not clearly depicted. Especially Treatment $\mathrm{C}$ showed contrary characteristics. It is possible that the application head did not work as well as expected and large amounts of water got lost in surface runoff, never reaching the taproot.

According to formula, the lower the required temperature increase in the water, the lower is the required energy for the same water amount. Treatments D and E showed that even at temperatures as low as $90^{\circ} \mathrm{C}$, dock control was successful with a high mortality rate (Figure 5).

The conversion of the logistic regression formula allowed us to derive the required quantities of water at different soil moisture levels and water temperatures for each application nozzle. As an example, Table 4 illustrates the amounts of water leading to a mortality rate of at

Table 3. Coefficients to formula (1) for each treatment.

\begin{tabular}{lcccccc} 
Coefficient & Interaction & \multicolumn{3}{c}{ Treatment } & & D \\
& & A & B & C & & \\
$\beta \operatorname{Tr}$ & treatment & 6.950 & 7.533 & 4.625 & 0.000 & 28.268 \\
$\beta \operatorname{TrT}$ & treatment:temperature & -0.042 & -0.055 & -0.028 & 0.000 & -0.284 \\
\hline$\beta \operatorname{TrM}$ & treatment:water-amount & -6.857 & -6.307 & -3.922 & 0.000 & -16.745 \\
$\beta \operatorname{TrTM}$ & treatment:temperature:water-amount & 0.046 & 0.047 & 0.016 & 0.000 & 0.174 \\
\hline
\end{tabular}

Table 4. Water, energy and fuel-oil requirement at an assumed water temperature of $90^{\circ} \mathrm{C}$ and a soil moisture content of 40 vol. $-\%$, determined by multiple regression.

\begin{tabular}{|c|c|c|c|c|c|c|}
\hline \multirow[t]{2}{*}{ Parameter } & \multirow[t]{2}{*}{ Unit } & \multicolumn{5}{|c|}{ Treatment } \\
\hline & & A & B & C & D & E \\
\hline Amount of water per plant & $\mathrm{dm}^{3}$ & 3.7 & 2.6 & 3.8 & 1.9 & 1.6 \\
\hline Energy per plant & $\mathrm{kWh}$ & 0.319 & 0.228 & 0.333 & 0.161 & 0.139 \\
\hline Fuel-oil requirement per plant theoretic & $\mathrm{dm}^{3}$ & 0.033 & 0.023 & 0.034 & 0.016 & 0.014 \\
\hline Fuel-oil requirement per $\mathrm{L}$ of water ${ }_{\text {measured }}-\mathrm{y}$ [fuel-oil]; $\mathrm{x}$ [water $90^{\circ} \mathrm{C}$ ] & $\mathrm{dm}^{3}$ & \multicolumn{5}{|c|}{$y=0.0118 x-R^{2}=0.77$} \\
\hline Fuel-oil requirement per plant measured & $\mathrm{dm}^{3}$ & 0.044 & 0.031 & 0.045 & 0.022 & 0.019 \\
\hline
\end{tabular}


least $80 \%$ at a soil moisture of 40 vol.- $\%$ and a water temperature of $90^{\circ} \mathrm{C}$. Listing the treatments in ascending order of the amount of water required, we have Treatments E, D, B, A and C. If we assume that the water is heated from 15 to $90^{\circ} \mathrm{C}$, it is possible to determine the theoretically required energy, and hence the theoretically required quantity of fuel-oil per plant (Table 4). In line with our expectations, the experimentally determined fuel-oil requirement for heating water was virtually the same for all treatments. Thus, we used a common regression equation for all collected data (regression equation in Table 4) to calculate the theoretical fuel-oil requirement per plant based on the theoretical quantities of water required per plant. Treatment $\mathrm{E}$ required the least amount of energy for a treatment success rate of $80 \%$.

\section{Water distribution in the soil-blue-dye tracing}

The individual figures showed sometimes a clearly limited and sometimes a highly diffuse water-distribution pattern in the soil (Figure 6). Not even in the plane of the roots was a defined contour recognisable. Contrary to our expectations, a water distribution depending on treatments could not be identified by visual examination. The statistical analysis of the summed-up water distribution from three sectional planes (Figure 7) revealed no significant differences between the individual treatments $(\mathrm{P}=0.38)$. In other words, none of the methods had significantly more blue-dyed areas within the assumed $0.1 \times 0.1 \times 0.1 \mathrm{~m}$ cube.

\section{Discussion}

The goal of this study was to optimise the application technology and energy consumption for hot-water treatments to control broad-leaved dock. The analysis showed that temperatures above $100^{\circ} \mathrm{C}$ were not necessary to achieve a mortality rate of at least $80 \%$. For Treatments D and $\mathrm{E}$, suitable results were obtained with water temperatures as low as $90^{\circ} \mathrm{C}$. Moreover, these two treatments required the lowest amounts of water and fuel-oil. Regarding energy requirements, Treatments D and $\mathrm{E}$ were the preferred treatments.

Soil moisture was an important treatment variable. The drier the soil conditions were, the less hot water was needed to get good mortality rates. It is important to note that the energy required for the heating of
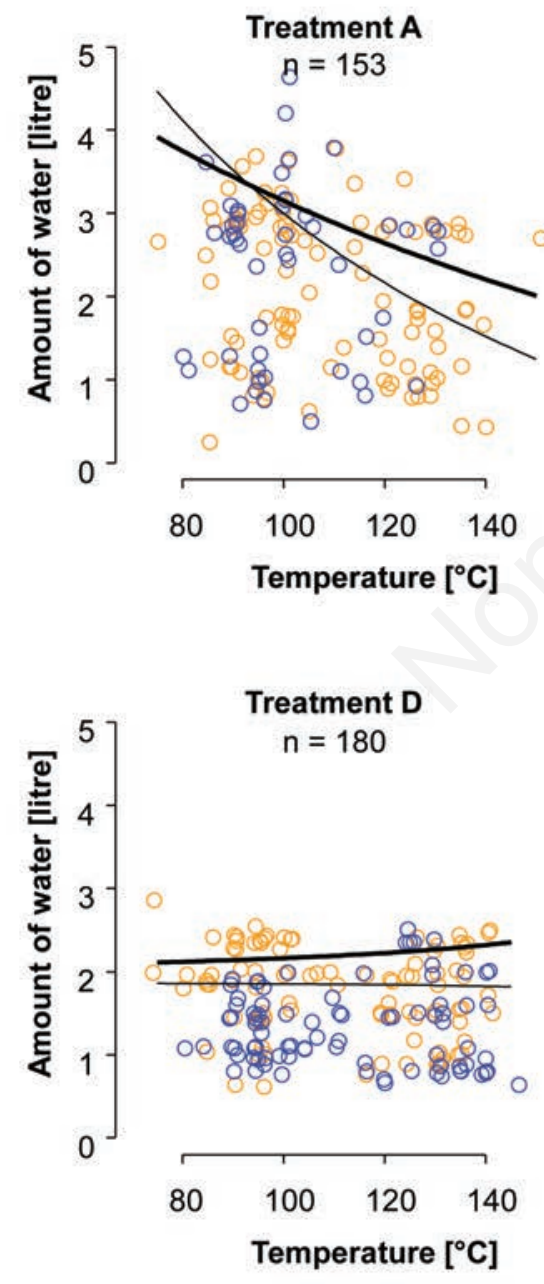
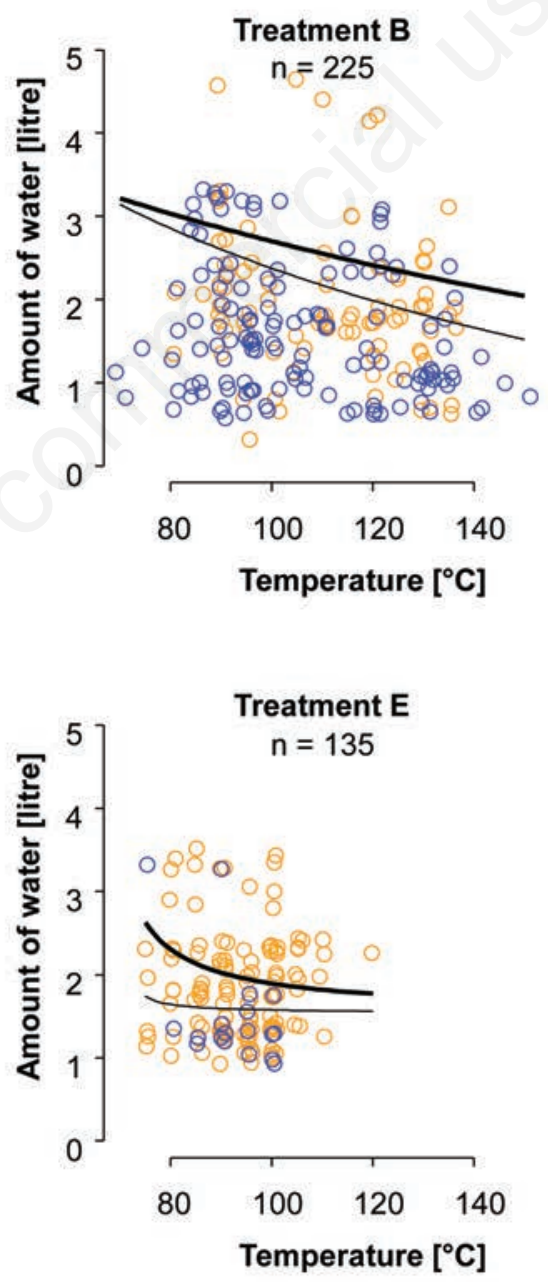
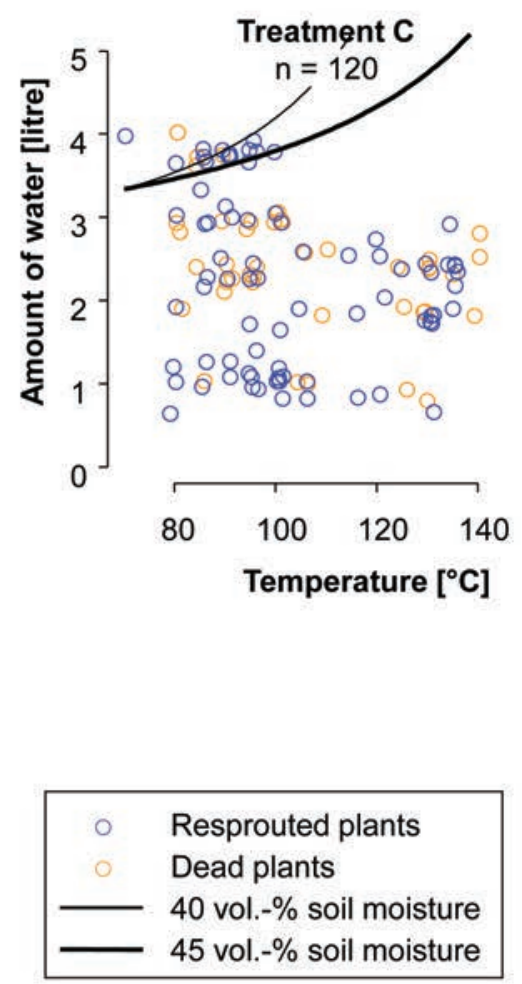

Figure 5. Dependency of mortality rate on amount of water, water temperature and soil moisture. Points lying above the regression lines have a probability of mortality greater than $80 \%$. 
additional soil moisture lowered the efficiency of the treatment because this energy was no longer available for the heating of the dock roots. This fact was represented in the statistical model, where soil moisture appeared as a main effect and in interaction with the amount of water. It can be expected that the soil type also had an effect - probably in interaction with soil moisture. This has to be investigated in further trials.

The ease of handling during the treatments was a criterion for the practicability of the method. The hammering of the application heads A-D proved cumbersome. Particularly with very dry soils rich in skeletal material, this action was very time consuming. Furthermore, with Treatment A, the heavy mechanical load on the mandrels caused them to break twice. This problem was solved by pre-boring the holes with an ancillary tool with the same geometry. Treatment E compared favourably here. The contact-free treatment of the plants from above entailed no additional labour or loss of time. The $10 \mathrm{~m}$ long hose and the low weight of the trigger gun guaranteed maximal mobility to treat the dock plants.

Observations in the field during the studies showed that with all treatments, a certain proportion of the water ran off above-ground, thereby remaining unused. This effect was most obvious in Treatment C. It was not possible to explain the differences in effect between the treatments by the blue-dye tests. The observation that with Treatment E the soil structure around the root was destroyed, and that the hot mud took some time to drain through fissures, was not reflected in the photos of the soil profile. The Vitasyn Blue dye tracer did not allow us to quantify the amount of water, but only enabled us to determine the spread of the water. Besides the spread of the hot water in the soil volume, other factors such as impact on the soil structure and transfer of the heat to the plant roots will need to be examined to explain how the hot-water treatments control dock plants.

Coarse compounds like rust, sand or limescale, which can obstruct the nozzles, must be filtered out directly at the water intake. Another problem is posed by calcification inside the machine. When the equipment is not in use, calcium carbonate precipitates as the hot water cools down inside the flow heater. This limescale cannot be filtered out and obstructs especially the small nozzle diameters of Treatments A and D. In Swiss and European organic farming, permitted cleansers such as formic acid or acetic and citric acid may not be used as additives in outdoor areas. To prevent calcification of the nozzles, it is advisable to use rainwater with a lime content as low as possible.

At an average treatment time of approximately $12 \mathrm{~s}$ for Treatment $\mathrm{E}$, the expected performance per hour on heavily weed-infested land was estimated at 150-180 plants per hour. Precise work-economics surveys on this subject have yet to be conducted.

\section{Conclusions}

The treatment of $R$. obtusifolius with hot water proved effective in the field trials. Treatment $\mathrm{E}$ emerged from the comparative study as the most efficient treatment. Based on a water requirement of approximately $1.6 \mathrm{dm}^{3}$ per plant, an energy requirement of $0.02 \mathrm{dm}^{3}$ fuel-oil per plant, an application time of approximately $12 \mathrm{~s}$, and its ease of use, this method was rated as suitable and favourable for practical application. Assuming that 2000 plants per hectare are treated with Treatment $\mathrm{E}$, this means an energy consumption of around $40 \mathrm{~L}$ of fuel-oil and a water consumption of $3200 \mathrm{~L}$.

Future studies should further optimise the energy and water requirement of the method, as well as enable recommendations for different site characteristics. The population density at which the use of the method is suitable must also be determined. The aim is to provide practitioners with precise treatment recommendations for a variety of soil types, soil moisture contents and population densities. In addition, the time spent for manual Rumex control must be estimated so that practitioners can quantify work performance and process costs.

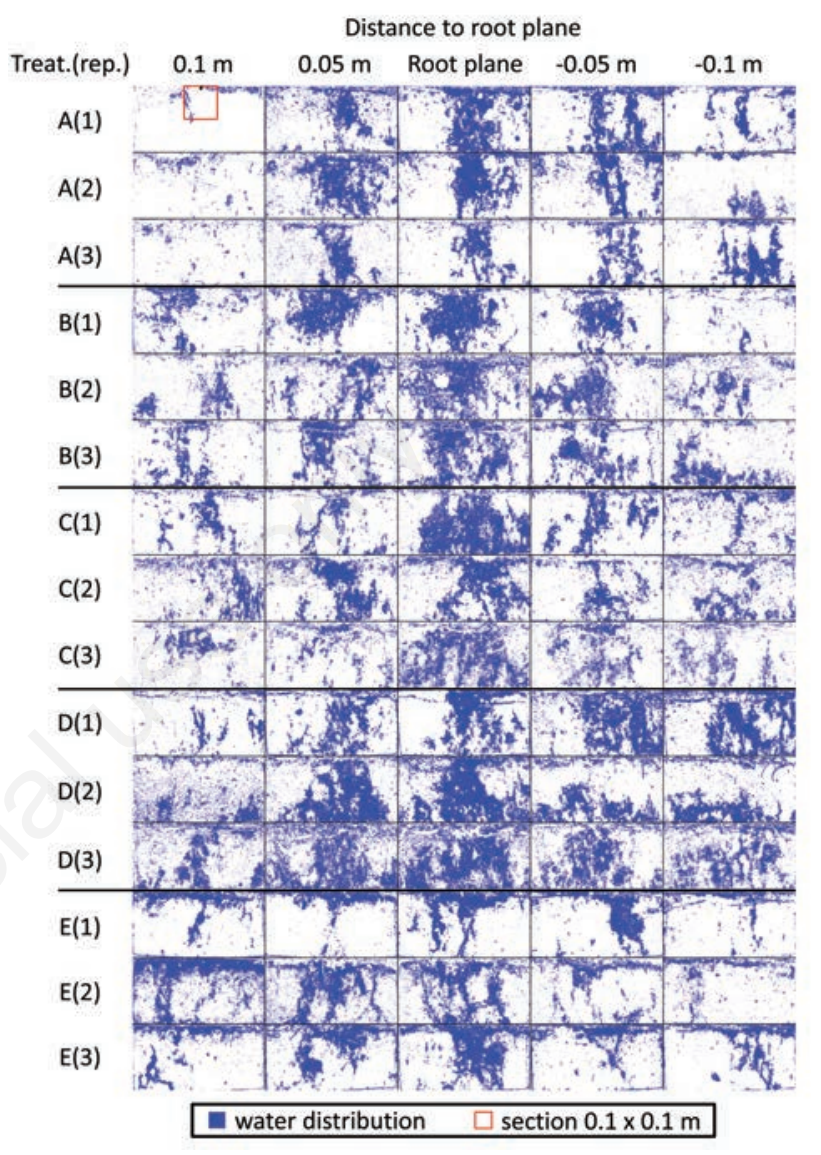

Figure 6. Combination of pictures showing the water distribution in the soil in triplicates for five treatments. Each rectangle represents a plane of $0.4 \times 0.2 \mathrm{~m}$. Treat., treatment; rep., repetition.

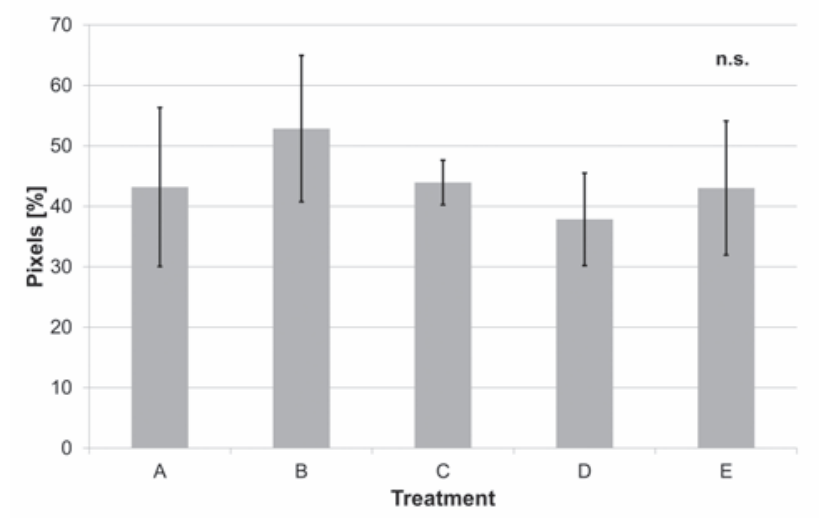

Figure 7. Percentage of pixels dyed blue in the sum of three sectional planes (mean and standard deviation). n.s., no significant differences. 
The described method of hot-water treatment is a solution for dock control in organic farming. Time will tell if this method could be suitable to control other root spreading weeds like creeping thistle (Cirsium arvense), bishop's weed (Aegopodium podagraria), common couch (Agropyron repens) and ragwort (Senecio jacobaea) or even invasive plants like yellow nutsedge (Cyperus esculentus) or Japanese knotweed (Reynoutria japonica).

\section{References}

Anken T., Irla E., Gysi M. 1999. Bildanalyse - billig und vielseitig einsetzbar. Agrarforschung. 6:240-1.

Barberi P., Moonen A.C., Peruzzi A., Fontanelli M., Raffaelli M. 2009. Weed suppression by soil steaming in combination with activating compounds. Weed Research. 49:55-66.

Barberi P., Moonen A.C., Raffaelli M., Peruzzi A., Belloni P., Mainardi M., Barberi P. 2002. Soil steaming with an innovative machine effects on actual weed flora. pp 238-41 in 5th EWRS Workshop on Physical and Cultural Weed Control, Pisa, Italy.

Bertram A. 1996. Geräte- und verfahrenstechnische Optimierung der thermischen Unkrautbekämpfung. Dissertation, Institut für Landtechnik der Technischen Universität München, München, Germany.

Böhm H., Finze J. 2004. Bericht zur Überprüfung der Effektivität der maschinellen Ampferregulierung im Grünland mittels WUZI unter differenzierten Standortbedingungen. Bundesforschungsanstalt für Landwirtschaft (FAL), Institut für ökologischen Landbau (OEL), Westerau, Germany.

Böhm H., Verschwele A. 2004. Ampfer- und Distelbekämpfung im ökologischen Landbau. pp 39-47 in Statusseminar 'Ressortforschung für den Ökologischen Landbau 2003', Kleinmachnow, Germany.

Boller M. 2006. Vergleich alternativer Methoden zur Regulierung von Wiesenblacken (Rumex obtusifolius L.). Semesterarbeit, ETHZ Eidgenössische Technische Hochschule Zürich, Departement Agrar- und Lebensmittelwissenschaften, Zürich, Switzerland.

Bond W., Turner R.J. 2003. The biology and non-chemical control of broad-leaved dock (Rumex obtusifolius L.) and curled dock (R. crispus L.). HDRA internal report. 16, Coventry, UK.

Briemle G., Rück K. 2006. Ampferbekämpfung durch Schafbeweidung Ergebnisse aus einem 5-jährigen Freilandversuch. Landinfo. 3:21-5.

Brune H. 1955. Experimentelle Untersuchungen am Wiederkäuer zur alimentären Wirksamkeit der nativen Oxalsäure. Zeitschrift für Tierernährung und Futtermittelkunde. 10:102-22.

Bundesamt für Statistik BfS 2012. STAT-TAB: Interaktive Statistikdatenbank: Landwirtschaft, Einheit: Betriebe, Beschäftigte, Nutzfläche in ha, Nutztier. Available from: http://www.pxweb.bfs.admin.ch/Database/German_07\%20\%20Land-\%20und\%20Forstwirtschaft/07.2\%20-\%20Landwirtschaft/ 07.2\%20-\%20Landwirtschaft.asp?lang=1\&prod=07 Accessed 21.02. 2013.

Cavers P.B., Harper J.L. 1964. Biological flora of the British Isles No. 98 Rumex obtusifolius L. and R. crispus L. J. Ecol. 52:737-66.

Dürr L., Anken T., Bollhalder H., Sauter J., Burri K.-G., Kuhn D. 2005. Machine vision detection and microwave based elimination of Rumex obtusifolius L. on grassland. Page 5 in 5th European Conference on Precision Agriculture, Uppsala, Sweden.

European Commission. 2008. Commission Regulation (EC) No. $889 / 2008$ of 5 September 2008 laying down detailed rules for the implementation of Council Regulation (EC) No. 834/2007 on organic production and labelling of organic products with regard to organic production, labelling and control. In: Official Journal L 250,
18/09/2008, pp 1-84.

Forschungsinstitut für biologischen Landbau FiBL (ed). 2014. Betriebsmittelliste 2014 - Hilfsstoffliste für den biologischen Landbau in der Schweiz. Frick, Switzerland.

Foster L. 1989. The biology and non-chemical control of dock species Rumex obtusifolius and Rumex crispus. Biol. Agric. Hortic. 6:11-25.

Gracia-López C., Velázquez-Martí B. 2002. Effects of microwave energy for agricultural soil processing. European Agricultural Engineering Congress (EurAgEng), Budapest, Hungary, 02-AE-026.

Grossrieder M., Keary I.P. 2004. The potential for the biological control of Rumex obtusifolius and Rumex crispus using insects in organic farming, with particular reference to Switzerland. Biocontrol News Inf. 25:65N-79N.

Hansson D., Mattsson J.E. 2002. Effect of drop size, water flow, wetting agent and water temperature on hot-water weed control. Crop Prot. 21:773-81.

Hopkins A., Johnson R.H. 2002. Effect of different manuring and defoliation patterns on broad-leaved dock (Rumex obtusifolius) in grassland. Ann. Appl. Biol. 140:255-62.

Hunt I.V., Harkess R.D. 1968. Docks in grassland. Scottish J. Agric. 47:160-2.

Kerpauskas P., Sirvydas A.P., Lazauskas R., Vasinauskiene R., Tamosiunas A. 2006. Possibilities of weed control by water steam. Agron. Res. 4:221-5.

Köpke U., Neuhoff D., Küpper P.M. 2011. Förderung des Ökologischen Landbaus - Deutschland im europäischen Vergleich. Institut für Organischen Landbau, Rheinische Friedrich-Wilhelms-Universität Bonn, Bonn, Germany.

Latsch R., Kaeser A., Sauter J. 2011. Hot water steam in dock control. Landtechnik. 66:170-2.

Latsch R., Sauter J. 2010. Microwave for dock control on grassland. EGF 2010 - Grassland in a changing world. European Grassland Federation EGF, Grassland Science in Europe, Kiel, Germany, 15:169-71.

Latsch R., Sauter J., Knížatová M. 2009. Dock-control via microwave energetic and financial considerations. Landtechnik. 64:350-3.

Massucati L.F.P., Windisch E., Täufer F., Köpke U. 2009. Kontrolle von Rumex spp. mit Citronella-Öl im Organischen Landbau. 10. Wissenschaftstagung Ökologischer Landbau: Werte - Wege Wirkungen: Biolandbau im Spannungsfeld zwischen Ernährungssicherheit, Markt und Klimawandel, Zürich, Band 1: Boden, Pflanzenbau, Agrartechnik, Umwelt- und Naturschutz, Biolandbau international, Wissensmanagement. Verlag Dr. Köster, Berlin, Germany, pp 280-3.

Mathiassen S.K., Bak T., Christensen S., Kudsk P. 2006. The effect of laser treatment as a weed control method. Biosyst. Engine. 95:497-505.

Merfield C.N., Hampton J.G., Wratten S.D. 2009. A direct-fired steam weeder. Weed Res. 49:553-6.

Niggli U., Nösberger J., Lehmann J. 1993. Effects of nitrogen fertilization and cutting frequency on the competitive ability and the regrowth capacity of Rumex obtusifolius L. in several grass swards. Weed Res. 33:131-7.

Oswald A.K., Haggar R.J. 1983. The effects of Rumex obtusifolius on the seasonal yield of two mainly perennial ryegrass swards. Grass Forage Sci. 38:187-91.

Peruzzi A., Raffaelli M., Frasconi C., Fontanelli M., Bàrberi P. 2012. Influence of an injection system on the effect of activated soil steaming on Brassica juncea and the natural weed seedbank. Weed Res. 52:140-52.

Peruzzi A., Raffaelli M., Ginanni M., Fontanelli M., Frasconi C. 2011. An innovative self-propelled machine for soil disinfection using steam and chemicals in an exothermic reaction. Biosyst. Engine. 110:434-42.

Peruzzi A., Raffaelli M., Ginanni M., Mainardi M. 2002. Development of 
innovative machines for soil disinfection by means of steam and substances in exothermic reaction. pp 220-9 in 5th EWRS Workshop on Physical and Cultural Weed Control, Pisa, Italy.

Pino J., Haggar R.J., Sans F.X., Masalles R.M., Hamilton R.N.S. 1995. Clonal growth and fragment regeneration of Rumex obtusifolius $\mathrm{L}$. Weed Res. 35:141-8.

Pötsch E.M. 2001. Wissenswertes zur mechanischen und chemischen Ampferbekämpfung. 7. Alpenländisches Expertenforum 'Bestandesführung und Unkrautregulierung im Grünland Schwerpunkt Ampfer', Bundesanstalt für alpenländische Landwirtschaft Gumpenstein, Irdning, Östereich, pp 75-81.

Pötsch E.M., Griesebner C. 2007. Control of broad-leaved dock on organic grassland farms. Grassland Sci. Eur. 12:138-41.

Roberts R.A., Hughes W.E. 1939. Biological studies in the control of docks (Rumex spp.). Welsh J. Agric. 15:218-37.

Roth L., Daunderer M., Kormann K. 2012. Giftpflanzen - Pflanzengifte. 6., überarbeitete Auflage. Nikol-Verlag, Hamburg, Germany.

Sauter J., Latsch R., Sauter M., Odermatt W. 2012. Mechanical weeding of Rumex obtusifolius in permanent grassland by removal of roots via a machinery process. International Conference of Agricultural Engineering 2012, Valencia, Spain, Conference proceeding on USB-Stick, C-0295, 6 .

Sirvydas A.P., Lazauskas P., Vasinauskieno R., Kerpauskas P. 2002. Thermal weed control by water steam. pp 253-62 in 5th EWRS Workshop on Physical Weed Control, Pisa, Italy.

Sobotik M. 2001. Verbreitung, Morphologie und Anatomie des Ampfers.
7. Alpenländisches Expertenforum 'Bestandesführung und Unkrautregulierung im Grünland - Schwerpunkt Ampfer', Bundesanstalt für alpenländische Landwirtschaft Gumpenstein, Irdning, Austria, pp 33-8.

Starz W., Steinwidder A., Angeringer W. 2010. Ampferregulierung durch intensive Beweidung möglich? Ergebnisse aus einem Exaktversuch sowie aus der Praxis. Fachtagung für Biologische Landwirtschaft - Weidehaltung im alpinen Raum, Irdning, Austria, pp 25-44.

Toole E., Brown E. 1946. Final results of the Duvel buried seed experiment. J. Agric. Res. 72:201-10.

Velázquez-Martí B., Gracia-López C. 2004. Thermal effects of microwave energy in agricultural soil radiation. Int. J. Infrared Millimeter Waves. 25:1109-22.

Velázquez-Martí B., Gracia-López C., de la Puerta R. 2008. Work conditions for microwave applicators designed to eliminate undesired vegetation in a field. Biosystems Engine. 100:31-7.

Zaller J.G. 2004. Ecology and non-chemical control of Rumex crispus and R. obtusifolius (Polygonaceae): a review. Weed Res. 44:414-32.

Zaller J.G. 2006. Sheep grazing vs. cutting: regeneration and soil nutrient exploitation of the grassland weed Rumex obtusifolius. BioControl. 51:837-50.

Zaller J.G. 2007. Seed germination of the weed Rumex obtusifolius after on-farm conventional, biodynamic and vermicomposting of cattle manure. Ann. Appl. Biol. 151:245-9. 